\title{
Kemik ve yumuşak doku sarkomları epidemiyolojisi ve genel sağ kalım özellikleri
}

\section{Bone and soft tissue sarcomas epidemiology and general survival characteristics}

Hüseyin Kaya ${ }^{1}$ (D) Dündar Sabah ${ }^{1}$ (D) Burçin Keçeci ${ }^{1}$ (D) Başak Doğanavşargil ${ }^{2-4}$ (iD) Murat Sezak ${ }^{2}$ (iD Banu Yaman ${ }^{2}$ Taner Akalın ${ }^{2}$ E. Serra Kamer ${ }^{3}$ (iD $\quad$ Yavuz Anacak $^{3}$ iD Ayfer Haydaroğlu ${ }^{3-4}$ (iD) Remide Arkun ${ }^{5}$ (i) Mehmet Argın $^{5}$ (iD) Ipek Tamsel ${ }^{5}$ (ID U. Ali Şanlı ${ }^{4-6}$ (iD Eda Ataseven ${ }^{7}$ (iD) Mehmet Kantar ${ }^{7}$ (iD)

${ }^{1}$ Ege Üniversitesi Tıp Fakültesi Ortopedi ve Travmatoloji Anabilim Dalı, İzmir, Türkiye

${ }^{2}$ Ege Üniversitesi Tıp Fakültesi Patoloji Anabilim Dalı, İzmir, Türkiye,

${ }^{3}$ Ege Üniversitesi Tıp Fakültesi Radyasyon Onkolojisi Anabilim Dalı, İzmir, Türkiye,

${ }^{4}$ Ege Üniversitesi Tıp Fakültesi Kanserle Savaş Araştırma ve Uygulama Merkezi

${ }^{5}$ Ege Üniversitesi Tıp Fakültesi Radyoloji Anabilim Dalı, İzmir, Türkiye,

${ }^{6}$ Ege Üniversitesi Tıp Fakültesi Medikal Onkolojisi Anabilim Dalı, İzmir, Türkiye,

${ }^{7}$ Ege Üniversitesi Tıp Fakültesi Pediatrik Onkolojisi Anabilim Dalı, İzmir, Türkiye

\section{Öz}

Amaç: Ege Üniversitesi Hastanesinde 1992-2017 arası kanser tanı ve tedavisi yapılan 3179 kemik ve yumuşak doku sarkomunun epidemiyolojik ve sağ kalım özelliklerinin analizi ve sonuçların kaynaklarla karşılaştırılmasıdır.

Gereç ve Yöntem: Ege Üniversitesi Kanserle Savaş Araştırma ve Uygulama Merkezi tarafından toplanan kemik ve yumuşak doku sarkomu verileri CANREG özel bilgisayar programına kayıt edilmiş, DSÖ ve SEER sistemleri temelinde gruplanarak analizler yapılmıştır. İstatistik analizlerde Ki-kare, General Linear Model, Kaplan Meier sağ kalım analizleri uygulanmıştır. Kaplan Meier sağ kalım analizinde Log Rank (Mantel-Cox), Breslow (Generalized Wilcoxon) ve Tarone-Ware istatistikleri kullanılmıştır. İstatistik analizlerde $\mathrm{p}<0,05$ istatistiksel olarak anlamlı kabul edilmiştir.

Bulgular: EÜH Kanser veri sisteminde bulunan 117.139 olgu arasında kemik ve yumuşak doku sarkomları \%2,7 ( $n=3179)$ oranında gözükmektedir. Kemik tümörlü olgularımızın \%58'i (n:795) erkek, \%42'si (n:566) kadındır. Olgularımızın büyük bölümü 10-19 $(\% 30,8)$ ve 20-29 (\%14,8) yaş aralığındadır. En sık yerleşim yeri alt ekstremite uzun kemiklerindedir $(\% 42,5)$. Histolojik tanılarda ise en sık osteosarkom ardından Ewing sarkomu ve kondrosarkom görülmektedir. Evrelendirmesi yapılabilen olguların \%41'nin (n:663) lokalize tümör, \%33,2'sinin lokal ileri evre ve \%25,8'inin ise uzak metastaz ile başvurduğu görüldü. Yapılan sağ kalım değerlendirmesinde kemik tümörlerinde toplam beş yıllık GSK \%62, 10 yıllık ise \%53 saptandı. Evrelere göre beş ve 10 yıllık GSK sırasıyla; lokalize tümörlerde $\% 71$ ve $\% 65$, lokal ileri evrede $\% 58$ ve $\% 54$, metastatik dönemde ise $\% 43$ ve $\% 36$ 'dır.

Yumuşak doku sarkomu olgularımızın \%53'ü (n: 970) erkek, \%47'si (n:847) kadındır. Evrelendirmesi yapılabilen olguların (n:739) \%49,9'unun lokalize tümör, \%24,1'inin lokal ileri evre ve \%26,2'sinin ise uzak metastaz ile başvurduğu görüldü. Yumuşak doku sarkomlarında toplam sağ kalım değerlendirmesinde beş yıllık GSK \%59, 10 yıllık \%49 saptandı. YDS da GSK'nin erkek hastalarda kadın hastalara göre daha kötü olduğu görüldü. Kadınlarda beş ve 10 yıllık GSK sırasıyla $\% 62$ ve $\% 53$ olarak saptanırken erkeklerde bu oranlar \%56 ve \%45'e düşmektedir.

Sonuç: EÜH Kanser veri sisteminde bulunan 117.139 olgu arasında kemik ve yumuşak doku sarkomları \%2,7 ( $n=3179)$ oranında gözükmektedir. Yapılan sağ kalım değerlendirmesinde kemik tümörlerinde beş yıllık GSK \%62, 10 yıllık ise \%53 saptandı. Yumuşak doku sarkomlarında beş yıllık GSK \%59, 10 yıllık \%49 saptandı.

Anahtar Sözcükler: Kemik ve Yumuşak doku sarkomu, epidemiyoloji, mortalite, genel sağ kalım.

\footnotetext{
Yazısma Adresi: Ayfer Haydaroğlu

Ege Üniversitesi Tıp Fakültesi, Radyasyon Onkolojisi

Anabilim Dalı, İzmir, Türkiye

E-mail: haydaroglua@gmail.com
} 


\begin{abstract}
Aim: To analyze the epidemiologic, and survival characteristics of 3179 bone and soft tissue sarcomas that were diagnosed as cancer and were treated in Ege University Hospital between 1992 and 2017, and compare the results with resources.

Materials and Methods: The data of the bone, and soft tissue sarcomas collected in Ege University Cancer Research Center were recorded in the CANREG special computer program, and the analyses were performed after grouping in the basis of the WHO, and SEER systems. The Chi-square, General Linear Model, Kaplan Meier survival analyses were performed in statistical analyses. Log Rank (Mantel-Cox), Breslow (Generalized Wilcoxon), and Tarone-Ware statistics were used in Kaplan Meier survival analysis. $p<0.05$ was accepted statistically significant in statistical analyses.
\end{abstract}

Results: The ratio of the bone, and soft tissue sarcomas were detected as $2.7 \%(n: 3179)$ among the 117.139 cases in Ege University Hospital Cancer data system. 58\% (n:795) of cases with bone tumor were men, and 42\%(n:566) were women. Majority of the cases were aged between 10-19 (30.8\%) years, and 20-29 (14.8\%) years. The most common settlement region was the lower extremity long bones (42.5\%). The most common histological diagnoses were osteosarcoma, Ewing sarcoma, and chondrosarcoma. We found that $41 \%(n: 663)$ of the cases that could be staged presented with localized tumor, and $33.2 \%$ presented with locally advanced stage, and $25.8 \%$ presented with distant metastasis. The survival evaluation showed that the total 5 years overall survival in bone tumors was $62 \%$, and 10 years overall survival was detected as 53\%. 5, and 10 years overall survival in accordance with the stages was $71 \%$, and $65 \%$ in localized tumors, $58 \%$, and $54 \%$ in locally advanced stage, and $43 \%$, and $36 \%$ in metastatic period.

53\% (n: 970) of the soft tissue sarcoma cases were men, and 47\%(n:847) were women. $49.9 \%(n: 739)$ of the cases that could be staged were found to have presented with localized tumor, $24.1 \%$ with locally advanced stage, and $26.2 \%$ presented with distant metastasis. 5 years overall survival was $59 \%$, and 10 years overall survival was detected as $49 \%$ in survival evaluation in soft tissue sarcomas. The overall survival in men in soft tissue sarcomas was detected to be poorer compared with the overall survival in women. Although 5 years, and 10 years overall survival was detected as $62 \%$, and $53 \%$ in women, the overall survival in 5 years, and 10 years decreased to $56 \%$, and $45 \%$, respectively in men.

Conclusion: The bone, and soft tissue sarcomas are found in a ratio of 2.7\%(n:3179) among 117.139 cases included in Ege University Hospital cancer data system. The survival evaluation showed that 5 years overall survival was 62\%, and 10 years overall survival was $53 \%$ in bone tumors. The 5 years overall survival in soft tissue sarcomas was $59 \%$, and 10 years overall survival was detected as $49 \%$.

Keywords: Bone and soft tissue sarcomas; epidemiology; mortality; overall survival.

\section{Giriş}

Kemik ve yumuşak doku sarkomları az sayıda görülen tümörlerdendir. Tüm malign tümörlerin yaklaşık \%1'ini kemik, \%1'ini yumuşak doku sarkomları (YDS) oluşturmaktadır (1, 2).

Kemik ve yumuşak doku sarkomlarının çok sayıda histolojik alt tipi tanımlanmıştır. Kemikte en sık osteosarkom, kondrosarkom ve Ewing sarkomu görülmektedir. YDS da ise pleomorfik sarkom, liposarkom, leiyomyosarkom, sinoviyal sarkom, malign periferal sinir kılıfı tümörü, rabdomyosarkom ve fibrosarkom olarak sıralamak mümkündür.

Kemik sarkomları arasında en sık görülen osteosarkom genellikle ikinci dekatta görülmektedir. İkinci ufak bir pik de 50-60 yaş üzerinde görülür. Genel olarak kadın erkek görülme oranı 3/2'dir. Nöroektodermal kökenli Ewing sarkomu ise büyük oranda çocuk ve adölesan yaş grubunda karşımıza çıkmaktadır. Olguların \%50'den fazlası 10-20 yaşları arasında, yaklaşık \%25'i 10 yaş altındadır. Bir diğer primer kemik tümörü olan kondrosarkom en sık 30-60 yaş aralığında görülmektedir. Erkek cinsiyette 2/1 oranında daha sık görülmektedir (3).

Yumuşak doku sarkomları (YDS), mezenkimal hücrelerden gelişen nadir malign tümörlerdir. YDS vücudun her bölgesinde görülebilmekle beraber en sık ekstremitelerin geniş kas gruplarında görülmektedir (\%55-60). Ayrıca gövdede, abdominal bölge ve pelvis, baş ve boyunda oluşabilmektedir. Tüm yaş gruplarında görülmekle birlikte olguların yaklaşık yarısı 60 yaş ve üzerinde gözlenir. Ortalama görülme yaşı 50 'dir. Sıklık açısından cinsiyet arasında anlamlı 
bir fark yoktur. Rabdomyosarkom çocukluk çağında, sinoviyal sarkom ve fibrosarkom genç erişkin dönemde, pleomorfik sarkom, liposarkom ve leiyomyosarkom ise sıklıkla daha ileri yaşlarda ortaya çıkmaktadır.

Kemik ve yumuşak doku sarkomları; tanı, tedavi ve takibi açısından multidisipliner yaklaşımla bu konuda deneyimli merkezlerce tedavi edilmesi gereken hastalık grubudur. Kemik ve yumuşak doku sarkomları tedavisinde olguların çoğunda cerrahi gerekmektedir. Cerrahi tedavi öncesinde ve/veya sonrasında tanı ve tümörün derecesine bağlı olarak kemoterapi ve/veya radyoterapi uygulanabilmektedir (4). 1970'li yıllardan önce kemik ve yumuşak doku sarkomlarında uygulanan yaygın tedavi tutulmuş olan ekstremitenin radikal amputasyonu şeklindeydi. $\mathrm{Bu}$ radikal cerrahilere rağmen hastaların sağ kalım oranları ancak \%10 - 20 arasındaydı $(5,6)$. 1980 'lerden sonra etkili kemoterapotik ilaçların ve tedavi protokollerinin geliştirilmesi, radyoterapi tedavilerinin eklenmesi sonucu sağ kalım oranlarında artış olmuştur. Aynı zamanda bilgisayarlı tomografi ve manyetik rezonans gibi görüntüleme yöntemlerinde teknolojik ilerleme beraberinde rekonstrüktif mikrocerrahideki gelişmeler sonucu kemik ve yumuşak doku sarkomları tedavisinde amputasyon oranları \%10'a düşmüştür (7).

Genellikle genç popülasyonu ilgilendiren kemik sarkomlarında modern tedavi yöntemlerinin gelişmesine rağmen en iyi şartlarda dahi beş yıllık sağ kalım oranları \%50-65 civarındadır. YDS'lerde ise \%50-75 olarak bildirilmektedir (8, 9).

$\mathrm{Bu}$ makalede Ege Üniversitesi Hastanesi (EÜH)'de 1992-2017 arası kanser tanı ve tedavisi yapılan 3179 kemik ve yumuşak doku sarkomunun epidemiyolojik ve genel sağ kalım özellikleri araştırımış, sonuçlar literatürle karşılaştırılmıştır.

\section{Gereç ve Yöntem}

EÜ Kanser Araştırma Merkezi (EÜKAM) tarafından 1992-2017 arası EÜH'de toplanan kemik ve yumuşak doku sarkomlarının verileri CANREG özel bilgisayar programına kaydedilmiştir. Bu veriler DSÖ ve SEER sistemleri temelinde gruplanarak analizler yapılmıştır. İstatistik analizlerde Ki-kare, General Linear Model (GLM), Kaplan-Meier sağ kalım analizleri uygulanmıştır. Kaplan-Meier sağ kalım analizinde Log Rank (Mantel-Cox), Breslow
(Generalized Wilcoxon) ve Tarone-Ware istatistikleri kullanımıştır. İstatistik analizlerde $p<0,05$ istatistiksel olarak anlamlı kabul edilmiştir

\section{Bulgular}

EÜH Kanser veri sisteminde bulunan 117.139 olgu arasında kemik ve yumuşak doku sarkomları $\% 2,7 \quad(n=3179)$ oranında gözükmektedir. Kemik sarkomları tüm kanser olgularının \%1.16'sını (n:1362) oluşturmaktadır. Kemik sarkomlarının cinsiyetlere göre dağılımı incelendiğinde erkek/kadın oranının 1,4 olduğu görülmektedir. Olgularımızın \%58'i (n:795) erkek, \%42'si (n:566) kadındır (Şekil-1). Olgularımızın büyük bölümü $10-19 \quad(\% 30,8)$ ve $20-29 \quad(\% 14,8)$ yaş aralığındadır (Tablo-1, Şekil-1 ve 2).

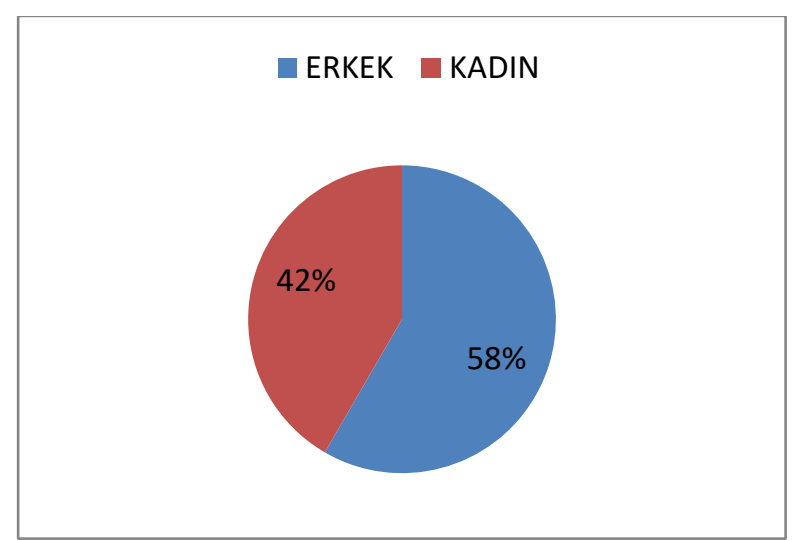

Şekil-1. Kemik tümörlerinin cinsiyetlere göre dağııımı.

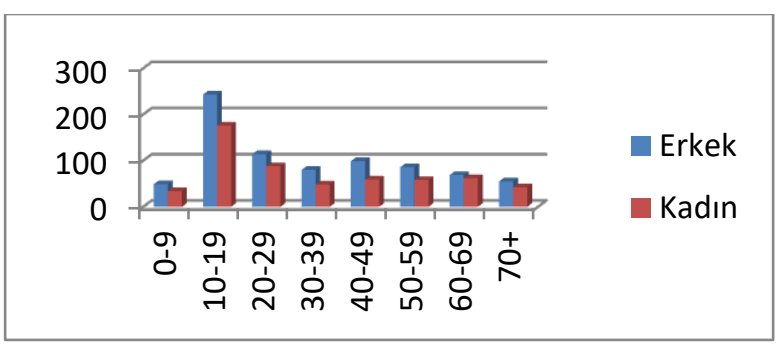

Şekil-2. Kemik tümörleri yaş grupları ve cinsiyet dağılımı.

Kemik sarkomlu olgularımızda tümörün en sık yerleşim yeri alt ekstremite uzun kemiklerindedir $(\% 42,5)$ (Tablo-2). Yerleşim yeri açısından yaş grupları ve cinsiyetler arasında fark saptanmamıştır (Tablo 3 ve 4, Şekil 3 ve 4).

Histolojik tanılarda ise en sık osteosarkom $(\% 30,4)$, Ewing sarkomu (\%19) ve kondrosarkom $(\% 17,3)$ görülmektedir (10) (Tablo 5 ve 6, Şekil 5 ve 6 ). Karsinom metastazları ve multiple myelom olguları dahil edilmemiştir. 
Tablo-1. Kemik tümörleri yaş grupları ve cinsiyet dağılımı.

\begin{tabular}{|c|c|c|c|c|c|c|}
\hline \multirow{2}{*}{ Yaş Grubu } & \multicolumn{2}{|c|}{ Erkek } & \multicolumn{2}{|c|}{ Kadın } & \multicolumn{2}{|c|}{ Toplam } \\
\hline & $\mathbf{n}$ & $\%$ & $\mathbf{n}$ & $\%$ & $\mathbf{n}$ & $\%$ \\
\hline $0-9$ & 49 & 6,2 & 34 & 6,0 & 83 & 6,1 \\
\hline $10-19$ & 243 & 30,6 & 176 & 31,1 & 419 & 30,8 \\
\hline $20-29$ & 114 & 14,3 & 88 & 15,5 & 202 & 14,8 \\
\hline 30-39 & 80 & 10,1 & 48 & 8,5 & 128 & 9,4 \\
\hline $40-49$ & 99 & 12,5 & 59 & 10,4 & 158 & 11,6 \\
\hline $50-59$ & 86 & 10,8 & 58 & 10,2 & 144 & 10,6 \\
\hline $60-69$ & 69 & 8,7 & 62 & 11,0 & 131 & 9,6 \\
\hline $70+$ & 55 & 6,9 & 42 & 7,4 & 97 & 7,1 \\
\hline $\begin{array}{c}\text { Toplam } \\
\text { Ki-kare: } 4,471 ; p=0,724\end{array}$ & 795 & 100,0 & 566 & 100,0 & 1362 & 100,0 \\
\hline
\end{tabular}

Tablo-2. Kemik tümörleri ICD-O3'e göre yerleşimler.

\begin{tabular}{lll} 
Kemik ve Eklem Tümörleri & \multicolumn{1}{c}{ Toplam } \\
C40.0 Üst ekstremite uzun kemik & $\mathrm{n}$ & $\%$ \\
C40.1 Üst ekstremite kısa kemik & 166 & 12,2 \\
C40.2 Alt ekstremite uzun kemik & 24 & 1,8 \\
C40.3 Alt ekstremite kısa kemik & 579 & 42,5 \\
C40.9 Ekstremite kemikleri, BBT & 50 & 3,7 \\
C41.0 Kafa, yüz kemik & 23 & 1,7 \\
C41.1 Mandibula & 76 & 5,6 \\
C41.2 Omurga/Vertebra & 29 & 2,1 \\
C41.3 Kosta, Sternum, Klavikula & 117 & 8,6 \\
C41.4 Pelvik kemik (Sakrum, Koksiks) & 84 & 6,2 \\
C41.8 Kemik Aşan lezyon & 180 & 13,2 \\
C41.9 Kemik, BBT & 5 & 0,4 \\
Toplam & 29 & 2,1 \\
\end{tabular}

Tablo 3. Kemik tümör yerleşimlerinin yaşam dönemlerine (çocuk ve erişkin) dağılımı.

\begin{tabular}{|c|c|c|c|c|c|c|}
\hline \multirow[t]{2}{*}{ Topografik Yerleşim } & $\begin{array}{l}\text { Çocuk } \\
(0-19 \text { y) }\end{array}$ & & $\begin{array}{l}\text { Erişkin } \\
(\geq 20 y)\end{array}$ & \multicolumn{3}{|c|}{ Toplam } \\
\hline & n $\quad \%$ & & $\%$ & & $\mathbf{n}$ & $\%$ \\
\hline C40.0 Üst ekstremite uzun kemik ve eklemler & 60 & 12,9 & 106 & 11,8 & 166 & 12,2 \\
\hline C40.1 Üst ekstremite kısa kemik ve eklemler & 4 & 0,9 & 20 & 2,2 & 24 & 1,8 \\
\hline C40.2 Alt ekstremite uzun kemik ve eklemler & 254 & 54,6 & 325 & 36,2 & 579 & 42,5 \\
\hline C40.3 Alt ekstremite kısa kemik ve eklemler & 19 & 4,1 & 31 & 3,5 & 50 & 3,7 \\
\hline C40.9 Ekstremite kemikleri, BBT & 12 & 2,6 & 11 & 1,2 & 23 & 1,7 \\
\hline C41.0 Kafa, yüz kemik ve eklemler & 21 & 4,5 & 55 & 6,1 & 76 & 5,6 \\
\hline C41.1 Mandibula & 6 & 1,3 & 23 & 2,6 & 29 & 2,1 \\
\hline C41.2 Omurga/Vertebra & 25 & 5,4 & 92 & 10,3 & 117 & 8,6 \\
\hline C41.3 Kosta, Sternum, Klavikula & 20 & 4,3 & 64 & 7,1 & 84 & 6,2 \\
\hline C41.4 Pelvik kemik ve eklemler (Sakrum, Koksiks) & 36 & 7,7 & 144 & 16,1 & 180 & 13,2 \\
\hline C41.8 Kemik ve eklem Aşan lezyon & 0 & 0,0 & 5 & 0,6 & 5 & 0,4 \\
\hline C41.9 Kemik, BBT & 8 & 1,7 & 21 & 2,3 & 29 & 2,1 \\
\hline Toplam** & 465 & 100,0 & 897 & 100,0 & 1362 & 100,0 \\
\hline
\end{tabular}


Ki-kare=62,600 p<0,001, *Sütun Yüzdesi, ${ }^{*}$ Satır Yüzdesi

Tablo-4. Kemik tümör yerleşimlerinin cinsiyetlere göre dağılımı.

\begin{tabular}{lrrrrrr} 
& \multicolumn{2}{c}{ Erkek } & \multicolumn{2}{c}{ Kadın } & \multicolumn{2}{c}{ Toplam } \\
Yerleşimler & $\mathbf{n}$ & $\%$ & $\mathbf{n}$ & $\%$ & $\mathbf{n}$ & $\%$ \\
C40.0 Üst ekstremite uzun kemik & 95 & 11,9 & 71 & 12,5 & 166 & 12,2 \\
C40.1 Üst ekstremite kısa kemik & 11 & 1,4 & 13 & 2,3 & 24 & 1,8 \\
C40.2 Alt ekstremite uzun kemik & 314 & 39,5 & 265 & 46,7 & 579 & 42,5 \\
C40.3 Alt ekstremite kısa kemik & 34 & 4,3 & 16 & 2,8 & 50 & 3,7 \\
C40.9 Ekstremite kemikleri, BBT & 14 & 1,8 & 9 & 1,6 & 23 & 1,7 \\
C41.0 Kafa, yüz kemik & 45 & 5,7 & 31 & 5,5 & 76 & 5,6 \\
C41.1 Mandibula & 17 & 2,1 & 12 & 2,1 & 29 & 2,1 \\
C41.2 Omurga/Vertebra & 80 & 10,1 & 37 & 6,5 & 117 & 8,6 \\
C41.3 Kosta, Sternum, Klavikula & 52 & 6,5 & 32 & 5,6 & 84 & 6,2 \\
C41.4 Pelvik kemik (Sakrum, Koksiks) & 114 & 14,3 & 66 & 11,6 & 180 & 13,2 \\
C41.8 Kemik Aşan lezyon & 2 & 0,3 & 3 & 0,5 & 5 & 0,4 \\
C41.9 Kemik, BBT & 17 & 2,1 & 12 & 2,1 & 29 & 2,1 \\
Toplam & 795 & $\mathbf{1 0 0 , 0}$ & $\mathbf{5 6 7}$ & $\mathbf{1 0 0 , 0}$ & $\mathbf{1 3 6 2}$ & $\mathbf{1 0 0 , 0}$ \\
\hline
\end{tabular}

Ki-kare=17,051 $\mathrm{P}=0,106$ Yerleşimlerde anlamlı fark yok, alt ekstremitelerde anlamlı fark.

Ki-kare $=7,917 \mathrm{p}<0,005$ cinsiyetler arası anlamlı fark.

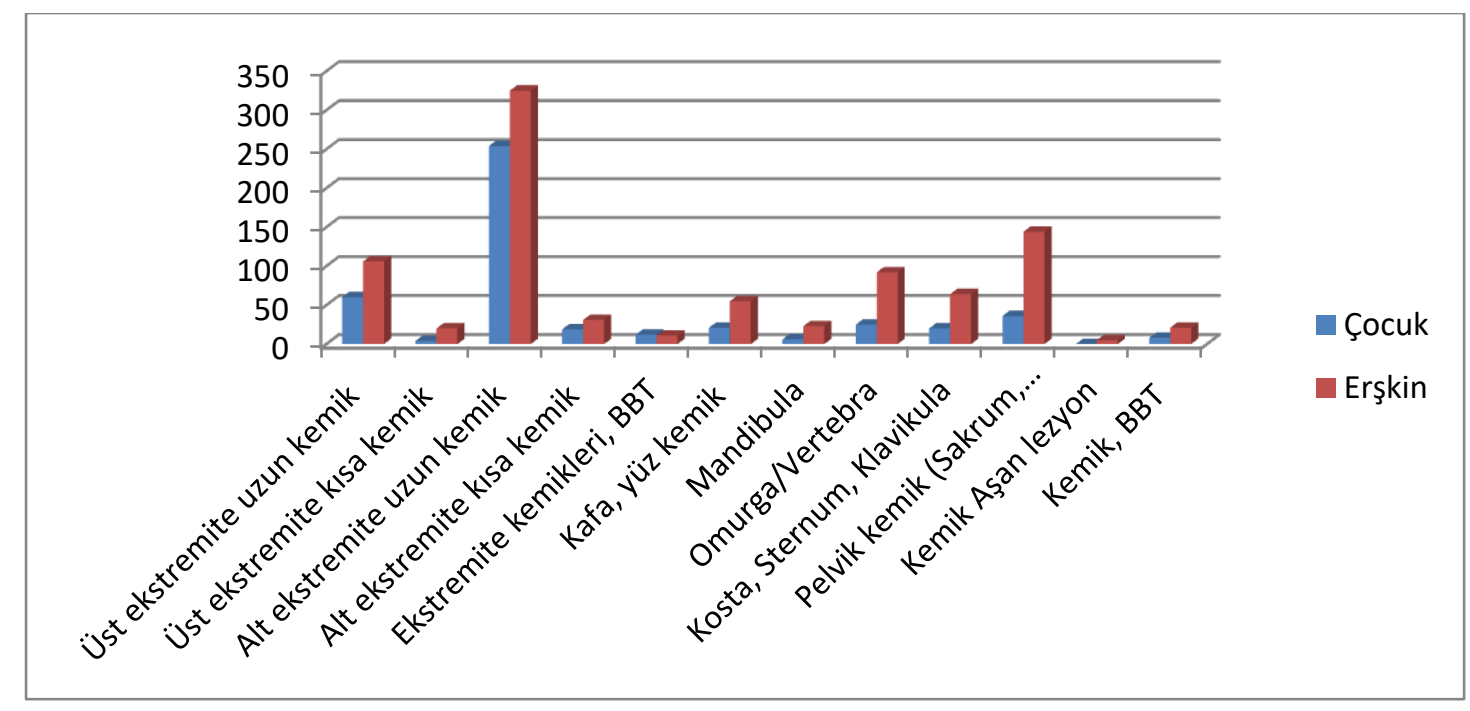

Şekil-3. Kemik tümör yerleşimlerinin yaşam dönemlerine (yaşam evreleri) dağılımı.

Evrelendirmesi yapılabilen olguların \%41'inin (n:663) lokalize tümör, \%33,2'sinin lokal ileri evre ve \%25.8'inin ise uzak metastaz ile başvurduğu görüldü. Cinsiyetler arasında tümör evreleri açısından fark saptanmadı (Tablo-7, Şekil-7).

Yapılan sağ kalım değerlendirmesinde kemik tümörlerinde toplam beş yıllık GSK \%62, 10 yıllık ise \%53 saptandı (Tablo-8, Şekil-8). GSK değerlendirmesinde cinsiyetler arası ve yaşam dönemleri arasında fark saptanmazken, 60 yaş ve üstü hastalarda GSK oranlarının belirgin düşük olduğu görüldü (Tablo-9 ve 10).

Histolojik alt tiplerde bu oran osteosarkom için beş yıllık \%56, 10 yıllık \%51 iken, Ewing sarkomunda sirasıyla $\% 57, \quad \% 48$ ve kondrosarkom için ise \%71, \%63'tür (Tablo-11, Şekil-9).

Evrelere göre beş ve 10 yıllık GSK sırasıyla; lokalize tümörlerde $\% 71$ ve \%65, lokal ileri 
evrede $\% 58$ ve $\% 54$, metastatik dönemde ise \%43 ve \%36'dır (Tablo-12, Şekil-10).

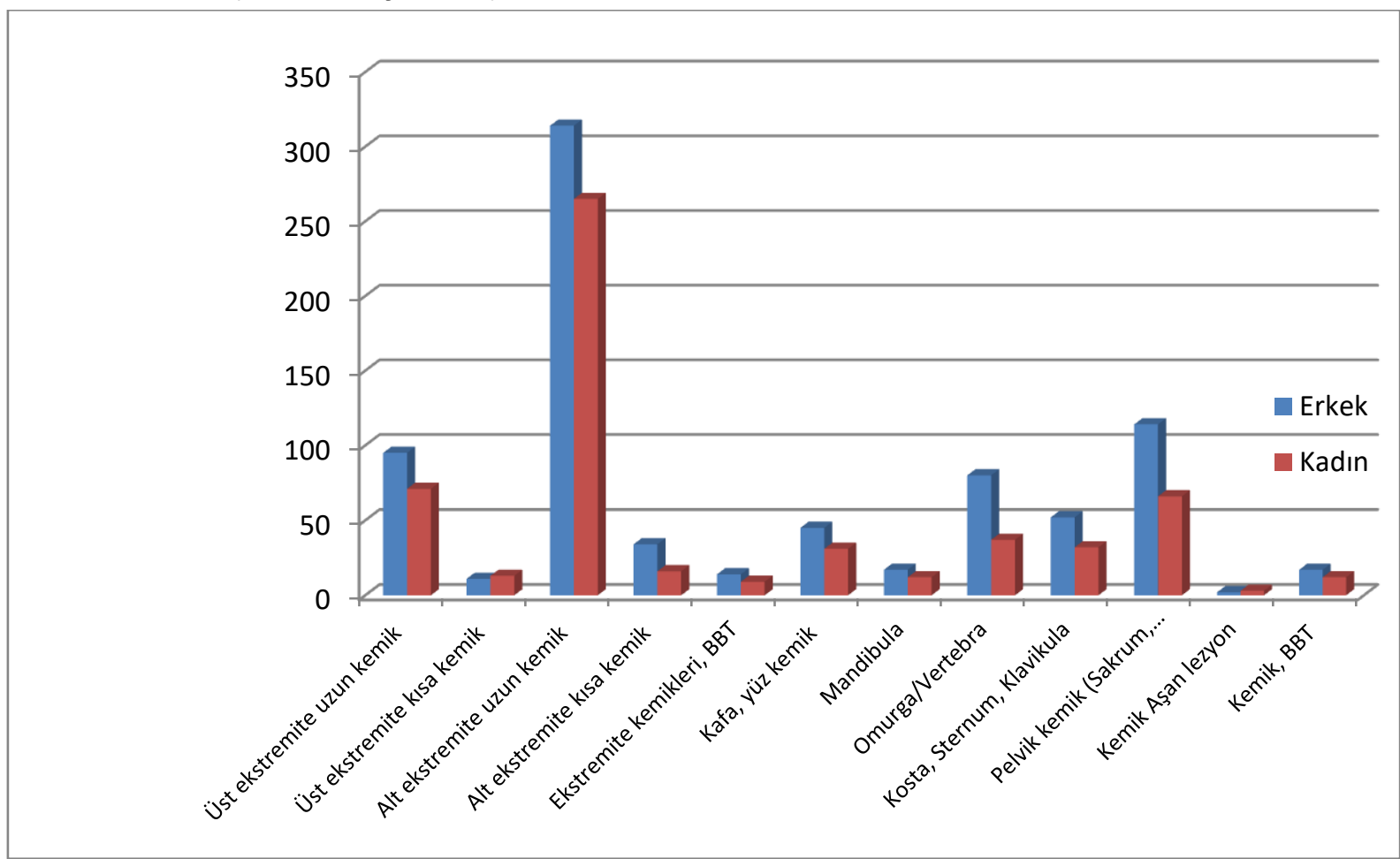

Şekil-4. Kemik tümör yerleşimlerinin cinsiyetlere dağılımı.

Tablo-5. Kemik tümör histolojilerinin cinsiyetlere dağılımı.

\begin{tabular}{lrrrrrr}
\hline Histoloji & Erkek & \multicolumn{2}{c}{ Kadın } & \multicolumn{2}{c}{ Toplam } \\
& $\mathbf{n}$ & $\%$ & $\mathbf{n}$ & $\%$ & $\mathbf{n}$ & $\%$ \\
\hline OSTEOSARKOM & 228 & 28,7 & 187 & 33 & 415 & 30,5 \\
EWING SARKOMU & 157 & 19,7 & 102 & 18 & 259 & 19 \\
KONDROSARKOM & 142 & 17,9 & 99 & 17,5 & 241 & 17,7 \\
KORDOMA & 39 & 4,9 & 22 & 3,9 & 61 & 4,5 \\
HEMATOPOETiK TÜMÖRLER & 112 & 14,1 & 74 & 13,1 & 186 & 13,7 \\
(PLAZMASiTOM, LENFOMA) & 6 & 0,8 & 5 & 0,9 & 11 & 0,8 \\
FiBROSARKOM & 6 & 0,8 & 9 & 1,6 & 15 & 1,1 \\
IĞSi HÜCRELI SARKOM, BBT & 13 & 1,6 & 4 & 0,7 & 17 & 1,2 \\
KÜÇÜK HÜCRELI SARKOM, BBT & 2 & 0,3 & 0 & 0 & 2 & 0,1 \\
MALIGN VASKULER TM & 37 & 4,7 & 28 & 4,9 & 65 & 4,8 \\
PLEOMORFIK SARKOM & 21 & 2,6 & 12 & 2,1 & 33 & 2,4 \\
SARKOM, BBT & 2 & 0,3 & 7 & 1,2 & 9 & 0,7 \\
INDiFERAN MALIGN TÜMÖR, BBT & 30 & 3,8 & 18 & 3,2 & 48 & 3,5 \\
Diğer & & & &
\end{tabular}




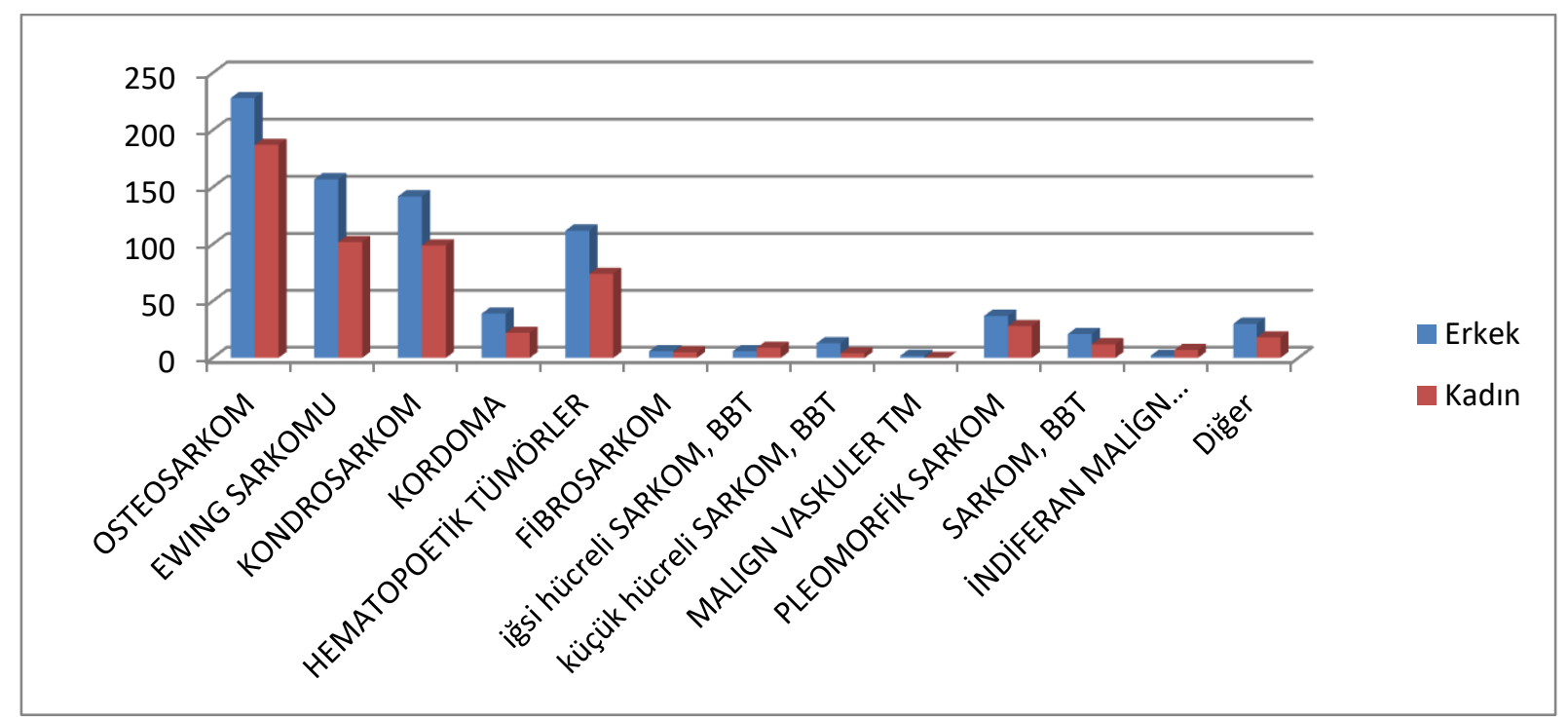

Şekil-5. Kemik tümör histolojilerinin cinsiyetlere dağılımı.

Tablo-6. Kemik tümör histolojilerinin yaşam dönemlerine dağılımı.

\begin{tabular}{|c|c|c|c|c|c|c|}
\hline & \multirow[t]{2}{*}{ Histoloji } & \multicolumn{2}{|c|}{$\begin{array}{l}\text { Çocuk } \\
(0-19 \text { y) }\end{array}$} & \multicolumn{2}{|c|}{$\begin{array}{l}\text { Erişkin } \\
(\geq 20 y) \\
\end{array}$} & \multirow[t]{2}{*}{ Toplam } \\
\hline & & $\mathbf{n}$ & $\%$ & $\mathbf{n}$ & $\%$ & \\
\hline & Osteosarkom & 215 & 51,8 & 200 & 48,2 & 415 \\
\hline & Ewing sarkomu & 167 & 64,5 & 92 & 35,5 & 259 \\
\hline & Kondrosarkom & 14 & 5,8 & 227 & 94,2 & 241 \\
\hline \multirow{12}{*}{ 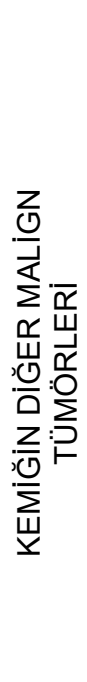 } & Kordoma & 2 & 3,3 & 59 & 96,7 & 61 \\
\hline & $\begin{array}{l}\text { Hematopoetik tümörler } \\
\text { (Plazmasitom, lenfoma) }\end{array}$ & 11 & 5,9 & 175 & 94,1 & 186 \\
\hline & Fibrosarkom & 3 & 27,3 & 8 & 72,7 & 11 \\
\hline & İğsi hücreli sarkom, BBT & 0 & 0,0 & 15 & 100,0 & 15 \\
\hline & Küçük hücreli sarkom, BBT & 10 & 58,8 & 7 & 41,2 & 17 \\
\hline & Malign vasküler tm & 0 & 0,0 & 2 & 100,0 & 2 \\
\hline & Pleomorfik sarkom & 6 & 9,2 & 59 & 90,8 & 65 \\
\hline & Sarkom, BBT & 8 & 24,2 & 25 & 75,8 & 33 \\
\hline & İndiferen malign tümör, BBT & 4 & 44,4 & 5 & 55,6 & 9 \\
\hline & Diğer & 23 & 47,9 & 48 & 100,0 & 48 \\
\hline & Toplam & 51 & 27,0 & 161 & 85,2 & 189 \\
\hline & Genel Toplam & 463 & 34,0 & 922 & 67,7 & 1362 \\
\hline
\end{tabular}




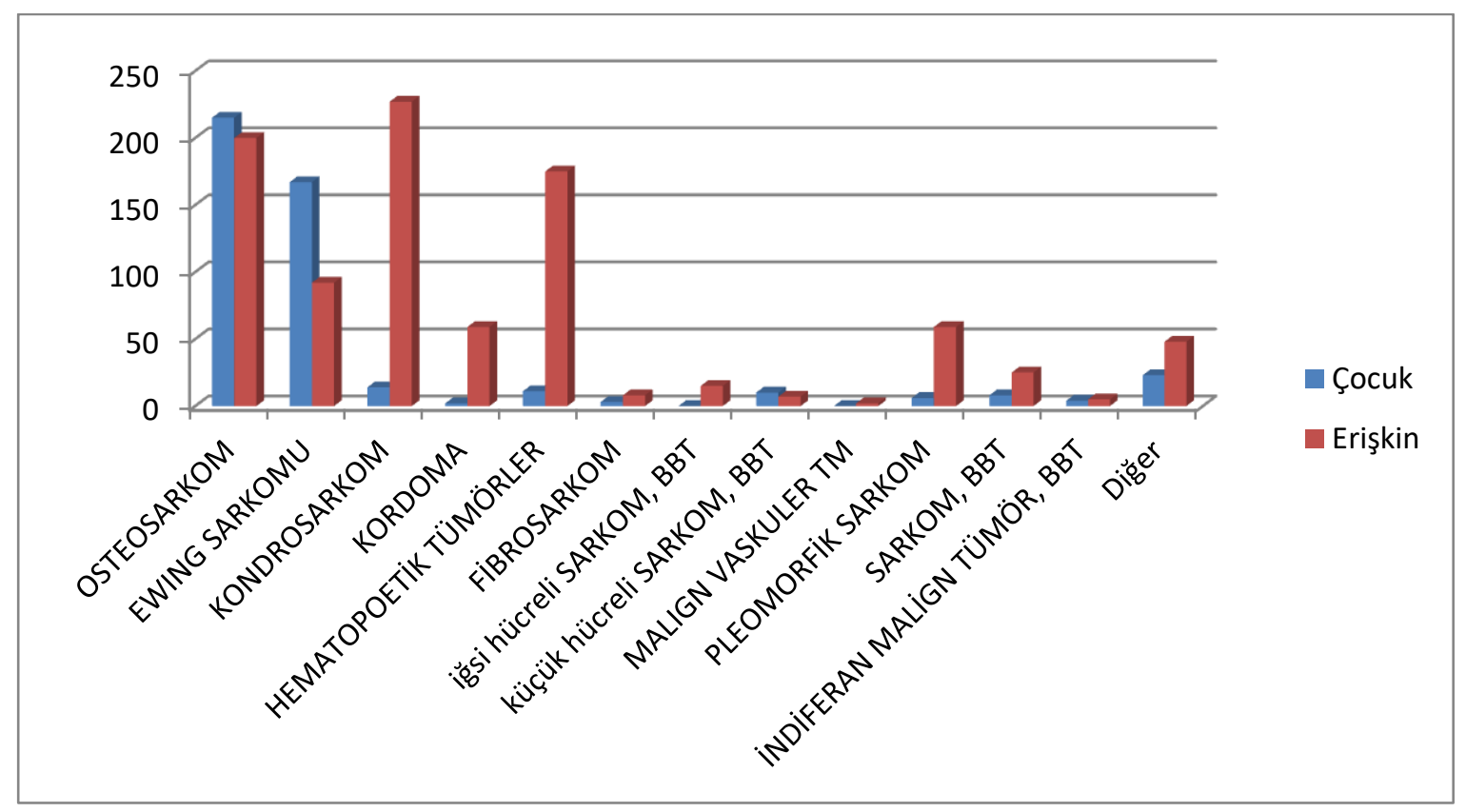

Şekil-6. Kemik tümör histolojilerinin yaşam dönemlerine (yaşam evresi) dağılımı.

Tablo-7. Kemik tümör evrelerinin cinsiyetlere dağılımı (bilinmeyenler hariç).

\begin{tabular}{lcccccc}
\hline \multirow{2}{*}{ Evreler } & \multicolumn{2}{c}{ Erkek } & \multicolumn{2}{c}{ Kadın } & \multicolumn{2}{c}{ Toplam } \\
& $\mathbf{n}$ & $\%$ & $\mathbf{n}$ & $\%$ & $\mathbf{n}$ & $\%$ \\
\hline Lokalize tümör & 161 & 41,2 & 111 & 40,8 & 272 & 41,0 \\
Lokal ileri & 129 & 33,0 & 91 & 33,5 & 220 & 33,2 \\
Uzak yayılım, metastaz & 101 & 25,8 & 70 & 25,7 & 171 & 25,8 \\
Toplam & 391 & 100,0 & 272 & 100,0 & 663 & 100,0 \\
\hline
\end{tabular}

Ki-kare: 0,066; $p=0992$

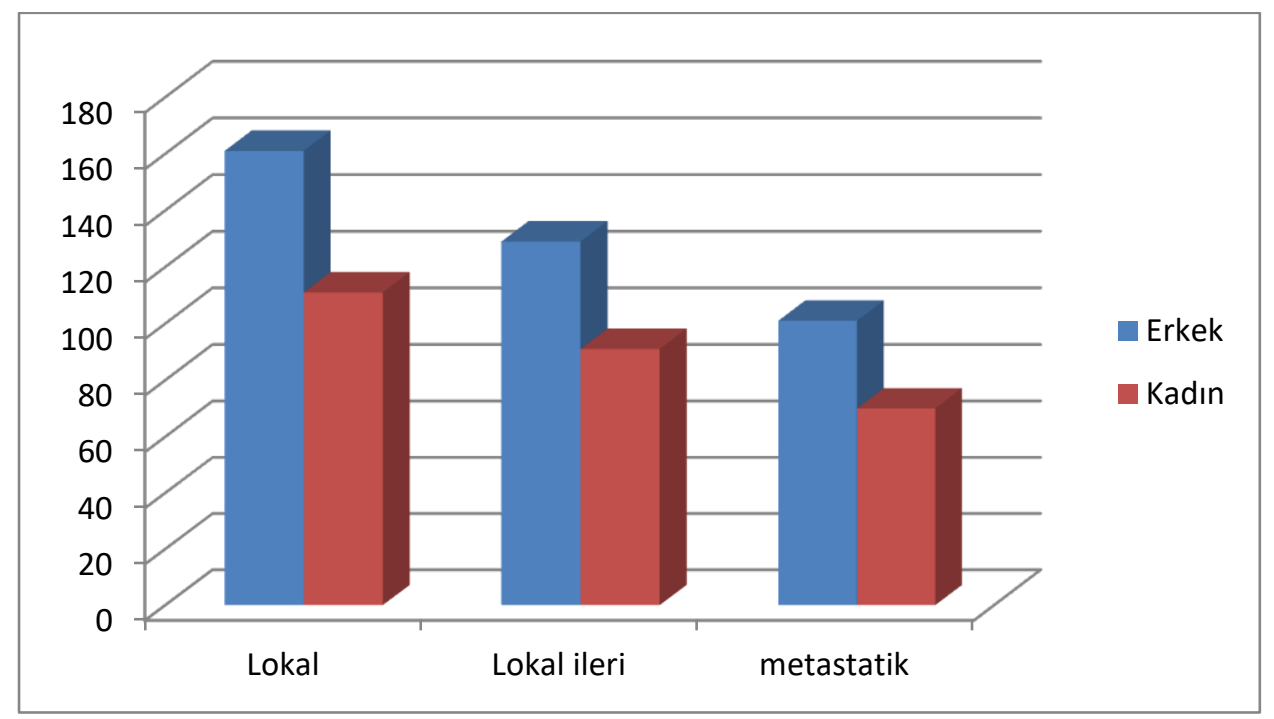

Şekil-7. Kemik tümör evrelerinin cinsiyetlere göre dağılımı. 


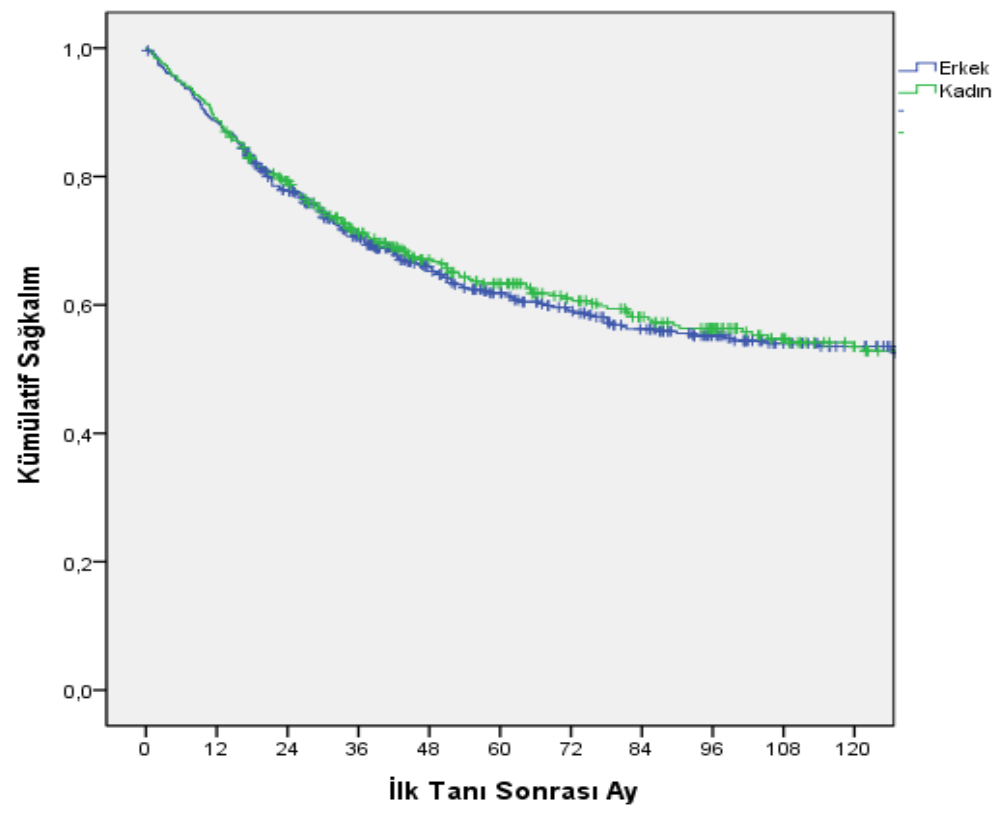

Şekil -8. Kemik tümörü cinsiyetlere göre sağ kalım.

Tablo-8. Kemik tümörleri sağ kalım oranları.

\begin{tabular}{cccccc}
\hline Cinsiyet & $\mathbf{n}$ & Ölüm & Yaşayan & $\mathbf{5}$ yıl & $\mathbf{1 0}$ Yıl \\
\hline Erkek & 507 & $\mathbf{n}$ & $\mathbf{\%}$ & 61 & 52 \\
Kadın & 369 & 157 & $57,50 \%$ & 63 & 53 \\
Toplam & $\mathbf{8 7 6}$ & $\mathbf{3 7 2}$ & $\mathbf{5 7 , 5 0 \%}$ & $\mathbf{6 2}$ & $\mathbf{5 3}$ \\
\hline
\end{tabular}

Tablo-9. Kemik tümörü yaşam dönemlerine göre sağ kalım.

\begin{tabular}{cccccc}
\hline & $\mathbf{n}$ & Ölüm & Yaşayan & \multirow{2}{*}{ yıl } & \multirow{2}{*}{ 10 Y.l } \\
\hline Çocuk & 305 & 126 & $58,70 \%$ & 63 & 56 \\
Erişkin & 571 & 246 & $56,90 \%$ & 62 & 52 \\
\hline
\end{tabular}

Tablo-10. Kemik tümörü yaş gruplarına göre sağ kalım.

\begin{tabular}{lccccc}
\hline \multicolumn{1}{c}{ Yaş Grubu } & $\mathbf{n}$ & $\begin{array}{c}\text { Ölüm } \\
\mathbf{n}\end{array}$ & $\begin{array}{c}\text { Yaşayan } \\
\text { \% }\end{array}$ & $\mathbf{5}$ yıl & 10 Yıl \\
\hline $0-9$ & 60 & 20 & $66,70 \%$ & 67 & 61 \\
$10-19$ & 265 & 110 & $58,50 \%$ & 63 & 56 \\
$20-29$ & 127 & 42 & $66,90 \%$ & 68 & 64 \\
$30-39$ & 80 & 26 & $67,50 \%$ & 71 & 60 \\
$40-49$ & 97 & 39 & $59,80 \%$ & 66 & 55 \\
$50-59$ & 100 & 44 & $56,00 \%$ & 61 & 53 \\
$60-69$ & 82 & 44 & $46,30 \%$ & 56 & 41 \\
$70+$ & 65 & 47 & $27,70 \%$ & 37 & 15 \\
\hline
\end{tabular}


Tablo-11. Kemik tümörlerinde histolojilere göre sağ kalım.

\begin{tabular}{lccccc}
\hline Histoloji & $\mathbf{n}$ & $\begin{array}{c}\text { Ölüm } \\
\mathbf{n}\end{array}$ & $\begin{array}{c}\text { Yaşayan } \\
\%\end{array}$ & $\mathbf{5}$ yıl & $\mathbf{1 0}$ Yıl \\
\hline OSTEOSARKOM & 249 & 117 & $53,00 \%$ & 56 & 51 \\
EWING SARKOMU & 177 & 84 & $52,50 \%$ & 57 & 48 \\
KONDROSARKOM & 143 & 49 & $65,70 \%$ & 71 & 63 \\
KORDOMA & 41 & 20 & $51,20 \%$ & 68 & 36 \\
\hline
\end{tabular}

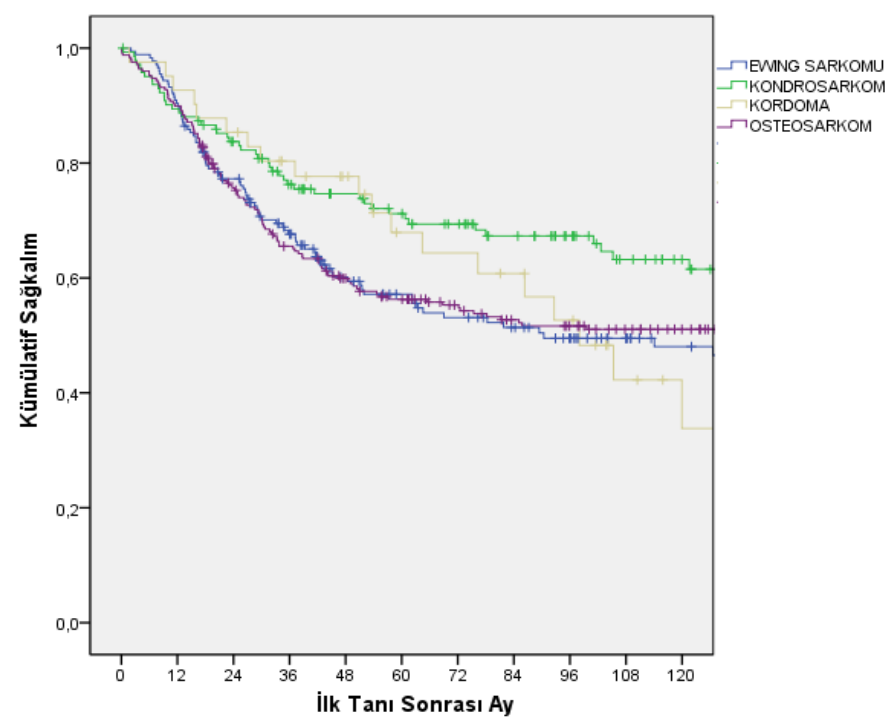

Şekil-9. Kemik tümörlerinde histolojilere göre sağ kalım.

Tablo-12. Kemik tümörlerinde evrelere göre sağ kalım.

\begin{tabular}{|c|c|c|c|c|c|}
\hline & $\mathbf{n}$ & $\begin{array}{c}\text { Ölüm } \\
n\end{array}$ & $\begin{array}{c}\text { Yaşayan } \\
\%\end{array}$ & $\begin{array}{c}5 \text { yil } \\
\%\end{array}$ & $\begin{array}{c}10 \text { YII } \\
\%\end{array}$ \\
\hline Lokal & 223 & 64 & $71,3 \%$ & 71 & 65 \\
\hline Lokal ileri & 146 & 62 & $57,5 \%$ & 58 & 54 \\
\hline metastatik & 113 & 69 & $38,9 \%$ & 43 & 36 \\
\hline
\end{tabular}

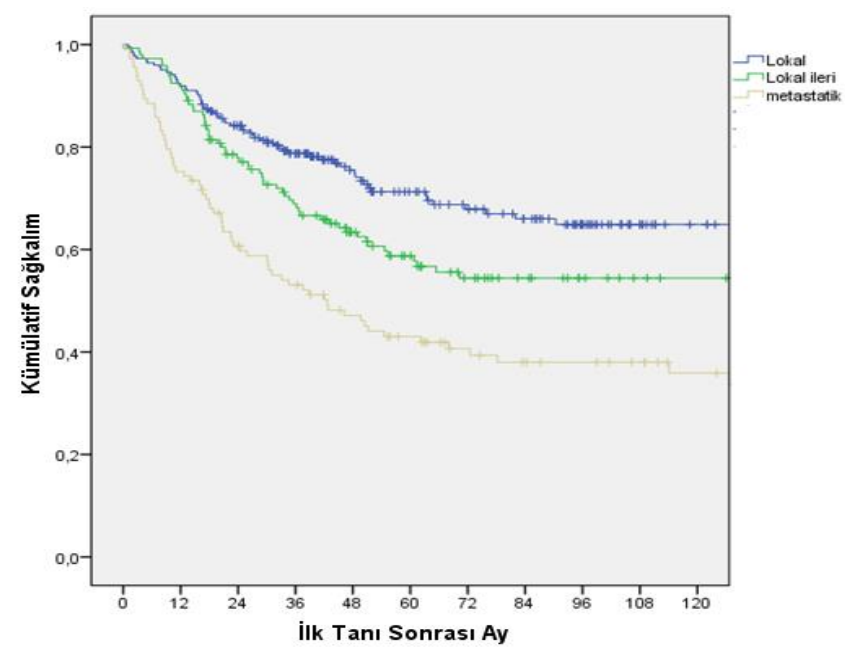

Şekil-10. Kemik tümörlerinde evrelere göre sağ kalım. 
Yumuşak doku sarkomları veri sisteminde bulunan tüm hastaların \%1,55'ini (n:1817) oluşturmaktadır. Yumuşak doku sarkomlarının cinsiyetlere göre dağılımı incelendiğinde erkek/kadın oranının 1,1 olduğu görülmektedir. Olgularımızın \%53'ü (n: 970) erkek, \%47'si (n: 847) kadındır (Şekil-11). Tüm yaş gruplarında görülmekle birlikte dördüncü dekattan itibaren daha sık oranda görülmektedir (Şekil-12). YDS yerleşim yerlerine göre yapılan değerlendirmede erişkin yaş grubunda belirgin oranda en sık alt ekstremite ve kalça (\%37) bölgesinde, ikinci sıklıkta ise pelvis $(\% 16,2)$ çevresinde saptandı. Çocuk yaş grubunda ise en sık alt ekstremite ve kalça $(\% 18,2)$ bölgesinde daha sonra karın bölgesinde $(\% 17,1)$ ve baş, yüz, boyun $(\% 16,8)$ bölgesinde saptandı (Tablo-13, Şekil-13).
Cinsiyetler arasında yerleşim yeri açısından fark saptanmadı (Tablo-14).

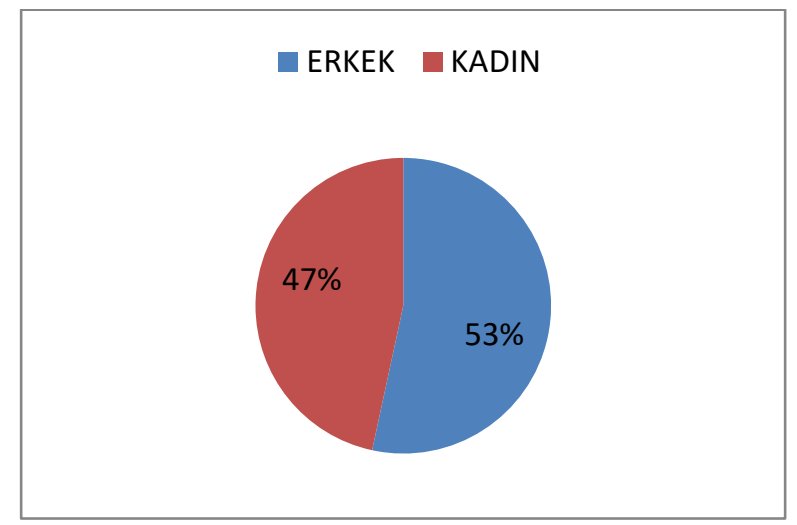

Şekil 11. Yumuşak doku sarkomlarının cinsiyetlere göre dağılımı.

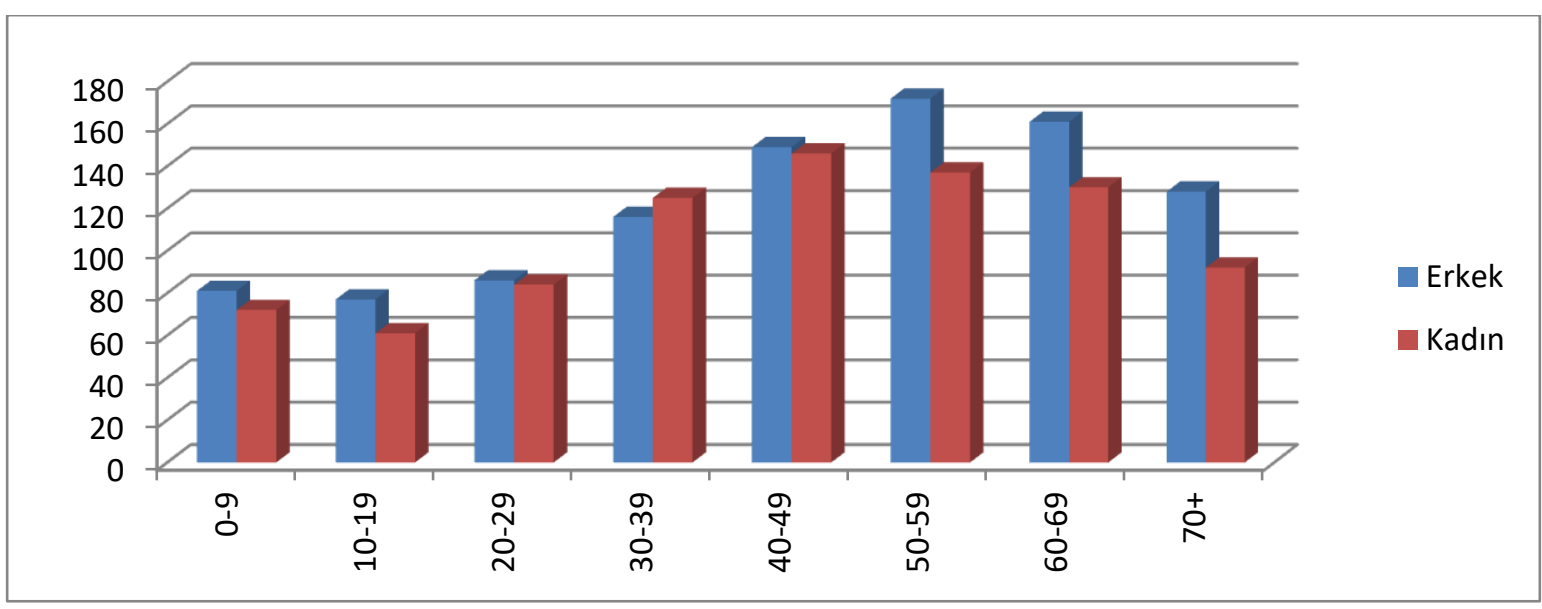

Şekil-12. Yumuşak doku sarkomları yaş grupları ve cinsiyet dağılımı.

Tablo-13. Yumuşak doku sarkomları yerleşimlerinin yaşam dönemlerine (yaşam evreleri) dağılımı.

\begin{tabular}{lrrrrrr}
\hline \multirow{2}{*}{ Topografik Yerleşim } & \multicolumn{2}{c}{ Çocuk } & \multicolumn{2}{c}{ Erişkin } & \multicolumn{2}{c}{ Toplam } \\
& $\mathbf{n}$ & \multicolumn{1}{c}{$\%$} & \multicolumn{1}{c}{ n } & \multicolumn{1}{c}{$\%$} & \multicolumn{1}{c}{$\mathbf{n}$} & \multicolumn{1}{c}{$\%$} \\
\hline Baş, yüz, boyun yumuşak dokular & 47 & 16,8 & 114 & 7,4 & 161 & 8,9 \\
Üst ekstremite \& omuz yumuşak doku & 28 & 10,0 & 180 & 11,7 & 208 & 11,4 \\
Alt ekstremite \& kalça yumuşak doku & 51 & 18,2 & 568 & 37,0 & 619 & 34,1 \\
Göğsün yumuşak dokuları & 33 & 11,8 & 124 & 8,1 & 157 & 8,6 \\
Karın yumuşak dokuları & 48 & 17,1 & 165 & 10,7 & 213 & 11,7 \\
Pelvis yumuşak dokuları & 42 & 15,0 & 249 & 16,2 & 291 & 16,0 \\
Gövde yumuşak dokuları & 11 & 3,9 & 57 & 3,7 & 68 & 3,7 \\
Yumuşak dokularda aşan lezyon & 4 & 1,4 & 7 & 0,5 & 11 & 0,6 \\
Diğer yumuşak dokular & 16 & 5,7 & 73 & 4,7 & 89 & 4,9 \\
Toplam & $\mathbf{2 8 0}$ & $\mathbf{1 0 0 , 0}$ & $\mathbf{1 5 3 7}$ & $\mathbf{1 0 0 , 0}$ & $\mathbf{1 8 1 7}$ & $\mathbf{1 0 0 , 0}$ \\
\hline
\end{tabular}

Ki-kare $=62,600 p<0,001$ 


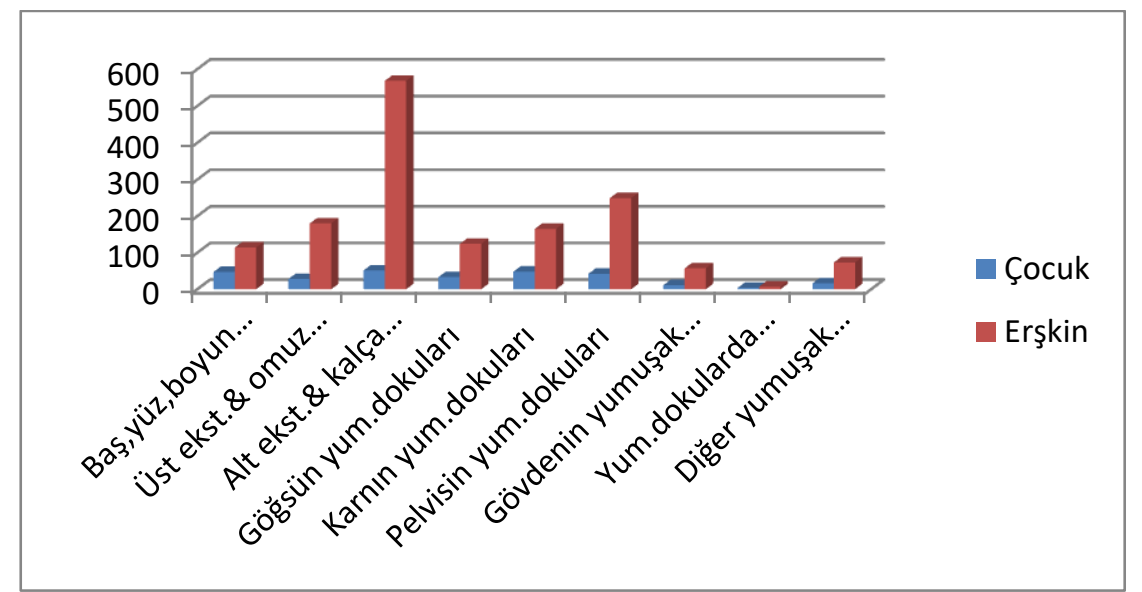

Şekil-13. Yumuşak doku sarkomları yerleşimlerinin yaşam dönemlerine (yaşam evreleri) dağılımı.

Tablo-14. Yumuşak doku sarkomları yerleşimlerinin cinsiyetlere dağılımı.

\begin{tabular}{lrrrrrr}
\hline \multirow{2}{*}{ Topografik Yerleşim } & \multicolumn{2}{c}{ Erkek } & \multicolumn{2}{c}{ Kadın } & \multicolumn{3}{c}{ Toplam } \\
& $\mathbf{n}$ & \multicolumn{1}{c}{$\%$} & $\mathbf{n}$ & \multicolumn{1}{c}{$\%$} & $\mathbf{n}$ & \multicolumn{1}{c}{$\%$} \\
\hline Baş, yüz, boyun yumuşak dokular & 96 & 9,9 & 65 & 7,7 & 161 & 8,9 \\
Üst ekstremite \& omuz yumuşak doku & 109 & 11,2 & 99 & 11,7 & 208 & 11,4 \\
Alt ekstremite \& kalça yumuşak doku & 312 & 32,2 & 307 & 36,2 & 619 & 34,1 \\
Göğsün yumuşak dokuları & 86 & 8,9 & 71 & 8,4 & 157 & 8,6 \\
Karın yumuşak dokuları & 104 & 10,7 & 109 & 12,9 & 213 & 11,7 \\
Pelvis yumuşak dokuları & 165 & 17,0 & 126 & 14,9 & 291 & 16,0 \\
Gövde yumuşak dokuları & 46 & 4,7 & 22 & 2,6 & 68 & 3,7 \\
Yumuşak dokularda aşan lezyon & 4 & 0,4 & 7 & 0,8 & 11 & 0,6 \\
Diğer yumuşak dokular & 48 & 4,9 & 41 & 4,8 & 89 & 4,9 \\
Toplam & $\mathbf{9 7 0}$ & $\mathbf{1 0 0 , 0}$ & $\mathbf{8 4 7}$ & $\mathbf{1 0 0 , 0}$ & $\mathbf{1 8 1 7}$ & $\mathbf{1 0 0 , 0}$ \\
\hline
\end{tabular}

Ki-kare $=12,894 p=0,116$

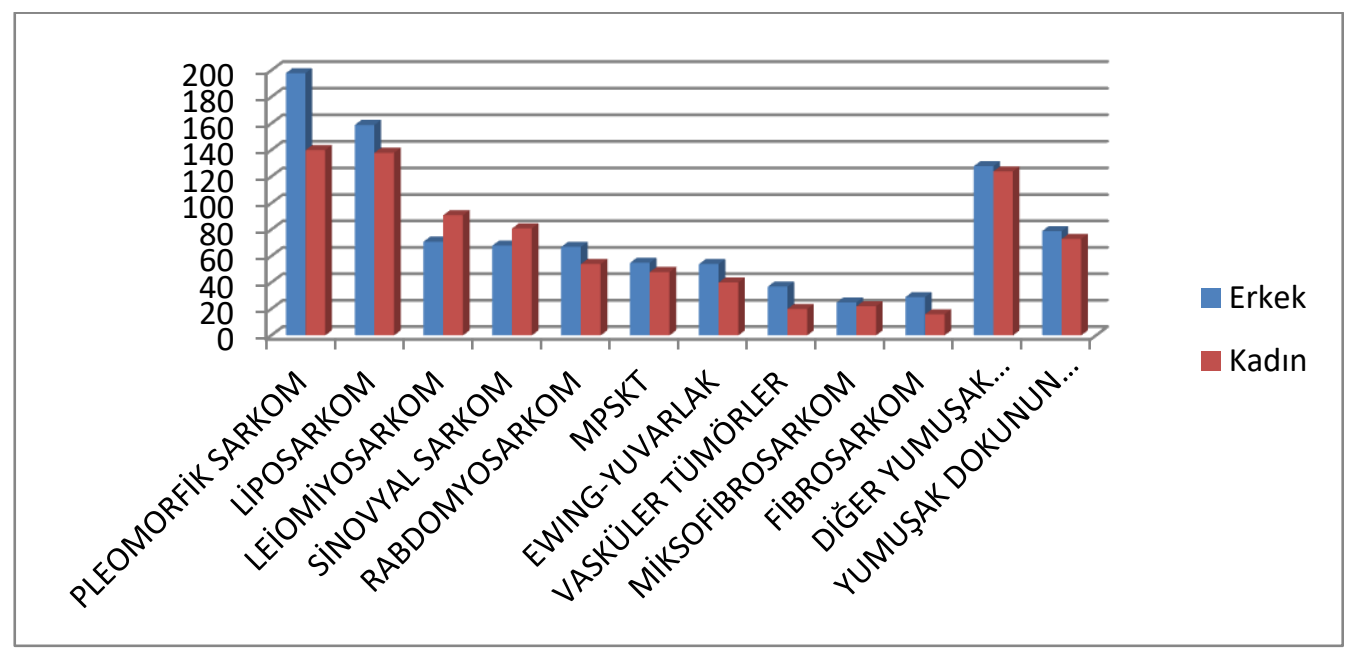

Şekil-14. Yumuşak doku sarkomları histolojilerinin cinsiyetlere göre dağılımı. 
YDS histolojik alt tiplerine göre dağılımı pleomorfik sarkom $(\% 18,6)$, liposarkom $(\% 16,3)$, leiyomyosarkom $(\% 8,9)$, sinoviyal sarkom $(\% 8,2)$, malign periferik sinir kılıfı tümörü $(\% 5,7)$ şeklindedir (Tablo-15 ve 16, Şekil-14).

Evrelendirmesi yapılabilen olguların ( $\mathrm{n}: 739)$ $\% 49,9$ 'unun lokalize tümör, \%24,1'inin lokal ileri evre ve \%26,2'sinin ise uzak metastaz ile başvurduğu görüldü. Cinsiyetler arasında tümör evreleri açısından fark saptanmadı (Tablo-17, Şekil-15).

Yumuşak doku sarkomlarında toplam sağ kalım değerlendirmesinde beş yıllık GSK \%59, 10 yıllık \%49 saptandı (Tablo-18).

Histopatolojik tanılara göre sağ kalımda liposarkomlar en iyi sağ kalıma sahipken malign periferik sinir kılıfı tümörünün en kötü orana sahip olduğu görüldü. Liposarkomlarda beş yıllık GSK $\% 80$ ve 10 yıllık \%69 iken MPSKT de \%36 ve $\% 27$, en sık görülen pleomorfik sarkomda sırasıyla \%59 ve \%49 saptandı (Tablo-19).

YDS da GSK'nin erkek hastalarda kadın hastalara göre daha kötü olduğu görüldü. Kadınlarda GSK beş ve 10 yıllık sırasıyla \%62 ve $\% 53$ olarak saptanırken erkeklerde bu oranlar $\% 56$ ve \%45'e düşmektedir (Tablo-18).

YDS de evrelere göre beş ve 10 yıllık GSK sırasıyla; Lokalize tümörlerde $\% 63$ ve $\% 56$, lokal ileri evrede $\% 49$ ve $\% 40$, metastatik dönemde ise \%19 ve \%14'tür (Tablo-20, Şekil-16).

Tablo-15. Yumuşak doku sarkomları histolojilerinin dağılımı.

\begin{tabular}{|c|c|c|}
\hline Histoloji & $\mathbf{n}$ & $\%$ \\
\hline PLEOMORFIK SARKOM & 338 & 18,6 \\
\hline LIPOSARKOM & 297 & 16,3 \\
\hline LEIOMYOSARKOM & 162 & 8,9 \\
\hline SINOVYAL SARKOM & 149 & 8,2 \\
\hline FIBROSARKOM & 45 & 2,5 \\
\hline MiKSOFIBROSARKOM & 47 & 2,6 \\
\hline MALIGN PERIFERIK SINIR KILIFI TM & 103 & 5,7 \\
\hline RABDOMYOSARKOM & 121 & 6,7 \\
\hline VASKÜLER TÜMÖRLER & 57 & 3,1 \\
\hline EWING-YUVARLAK HÜCRELI TM & 94 & 5,2 \\
\hline $\begin{array}{l}\text { DiĞER YUMUŞAK DOKU SARKOMLARI } \\
\text {-Epiteloid sarkom } \\
\text {-iğsi hücreli sarkom } \\
\text {-Yumuşak doku alveoler sarkom } \\
\text {-Şeffaf hücreli sarkom } \\
\text {-Dermatofibrosarkom } \\
\text {-Kondrosarkom } \\
\text {-Sarkom BBT } \\
\text {-Diğer }\end{array}$ & 252 & 13,9 \\
\hline $\begin{array}{l}\text { YUMUSAAK DOKUNUN DIĞER MALIGN TÜMÖRLERI } \\
\text {-İndeferen malign tümör } \\
\text {-Nöroblastom } \\
\text {-Lenfoma } \\
\text {-GiST } \\
\text {-Diğer }\end{array}$ & 152 & 8,4 \\
\hline Toplam & 1817 & 100,0 \\
\hline
\end{tabular}


Tablo-16. Yumuşak doku sarkomları histolojilerinin cinsiyetlere dağılımı.

\begin{tabular}{|c|c|c|c|c|c|}
\hline \multirow[b]{2}{*}{ Histoloji } & \multicolumn{2}{|c|}{ Erkek } & \multicolumn{2}{|c|}{ Kadın } & \multirow[b]{2}{*}{ Toplam } \\
\hline & $\mathrm{n}$ & $\%$ & $\mathbf{n}$ & $\%$ & \\
\hline PLEOMORFIK SARKOM & 198 & 58,6 & 140 & 41,4 & 338 \\
\hline LIPOSARKOM & 159 & 53,5 & 138 & 46,5 & 297 \\
\hline LEIOMYOSARKOM & 71 & 43,8 & 91 & 56,2 & 162 \\
\hline SINOVYAL SARKOM & 68 & 45,6 & 81 & 54,4 & 149 \\
\hline RABDOMYOSARKOM & 67 & 55,4 & 54 & 44,6 & 121 \\
\hline MPSKT & 55 & 53,4 & 48 & 46,6 & 103 \\
\hline EWING-YUVARLAK HÜC. TM & 54 & 57,4 & 40 & 42,6 & 94 \\
\hline VASKÜLER TÜMÖRLER & 37 & 64,9 & 20 & 35,1 & 57 \\
\hline MIKSOFIBROSARKOM & 25 & 53,2 & 22 & 46,8 & 47 \\
\hline FIBROSARKOM & 29 & 64,4 & 16 & 35,6 & 45 \\
\hline DIGGER YUMUŞAK DOKU SARKOMLARI & 128 & 50,8 & 124 & 49,2 & 252 \\
\hline YUMUŞAK DOKUNUN DIGĞER MALIGN TÜMÖRLERI & 79 & 52,0 & 73 & 48,0 & 152 \\
\hline TOPLAM & 970 & 53,4 & 847 & 46,6 & 1817 \\
\hline
\end{tabular}

Tablo-17. Yumuşak doku sarkomları evrelerinin cinsiyetlere dağılımı (bilinmeyenler hariç).

\begin{tabular}{lcccccc}
\hline \multirow{2}{*}{ Evreler } & \multicolumn{2}{c}{ Erkek } & \multicolumn{2}{c}{ Kadın } & \multicolumn{2}{c}{ Toplam } \\
& $\mathbf{n}$ & $\%$ & $\mathbf{n}$ & $\%$ & $\mathbf{n}$ & $\%$ \\
\hline Lokalize tümör & 188 & 46,9 & 180 & 53,3 & 368 & 49,9 \\
Lokal ileri & 97 & 24,2 & 81 & 24,0 & 178 & 24,1 \\
Uzak Yayılım Metastaz & 116 & 28,9 & 77 & 22,8 & 193 & 26,2 \\
Toplam & $\mathbf{4 0 1}$ & $\mathbf{1 0 0 , 0}$ & $\mathbf{3 3 8}$ & $\mathbf{1 0 0 , 0}$ & $\mathbf{7 3 9}$ & $\mathbf{1 0 0 , 1}$ \\
\hline
\end{tabular}

Ki-kare: 4,$152 ; p=0,125$

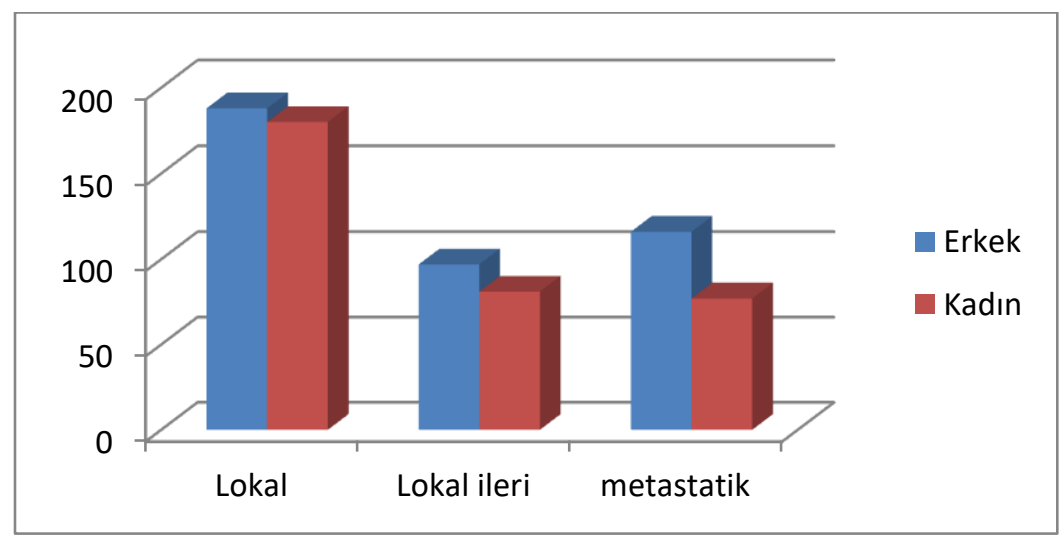

Şekil-15. Yumuşak doku sarkomları evrelerinin cinsiyetlere göre dağılımı.

Tablo-18. Yumuşak doku sarkomları sağ kalım oranları.

\begin{tabular}{lccccc}
\hline Yerleşim & $\mathbf{n}$ & Ölüm & $\begin{array}{c}\text { Yaşayan } \\
\text { \% }\end{array}$ & $\begin{array}{c}\mathbf{5} \text { yıl } \\
\%\end{array}$ & $\begin{array}{c}\mathbf{1 0} \text { Yıl } \\
\%\end{array}$ \\
\hline Erkek & 657 & 328 & $50,1 \%$ & 56 & 45 \\
Kadın & 600 & 258 & $57,0 \%$ & 62 & 53 \\
Toplam & $\mathbf{n}$ & $\mathbf{5 8 6}$ & $\mathbf{5 3 , 4 \%}$ & $\mathbf{5 9}$ & $\mathbf{4 9}$ \\
\hline
\end{tabular}


Tablo-19. Yumuşak doku sarkomları histolojilere göre sağ kalım oranları.

\begin{tabular}{lccccc}
\hline Histolojik alt tip & $\mathbf{n}$ & $\begin{array}{c}\text { Ölüm } \\
\mathbf{n}\end{array}$ & $\begin{array}{c}\text { Yaşayan } \\
\mathbf{\%}\end{array}$ & $\begin{array}{c}\mathbf{5} \text { yıl } \\
\%\end{array}$ & $\begin{array}{c}\mathbf{1 0} \text { Yıl } \\
\%\end{array}$ \\
\hline PLEOMORFIK SARKOM & & 132 & $44,10 \%$ & 59 & 49 \\
LiPOSARKOM & 236 & 66 & $70,10 \%$ & 80 & 69 \\
LEIOMYOSARKOM & 221 & 69 & $38,90 \%$ & 51 & 33 \\
SiNOVYAL SARKOM & 113 & 54 & $49,10 \%$ & 59 & 46 \\
MPSKT & 106 & 42 & $34,40 \%$ & 36 & 27 \\
TÜM YDS & 64 & $\mathbf{5 8 6}$ & $\mathbf{5 3 , 4 0 \%}$ & $\mathbf{5 9}$ & $\mathbf{4 9}$ \\
\hline
\end{tabular}

Tablo-20. Yumuşak doku sarkomları evrelerine göre sağ kalım oranları.

\begin{tabular}{|c|c|c|c|c|c|}
\hline YDS & $\mathbf{n}$ & $\begin{array}{c}\text { Ölüm } \\
\mathbf{n} \\
\end{array}$ & $\begin{array}{c}\text { Yaşayan } \\
\% \\
\end{array}$ & $\begin{array}{c}5 \text { yll } \\
\%\end{array}$ & $\begin{array}{c}10 Y_{\text {Il }} \\
\%\end{array}$ \\
\hline Lokal & 339 & 127 & $62,5 \%$ & 63,2 & 56,2 \\
\hline Lokal ileri & 146 & 79 & $45,9 \%$ & 49,1 & 40,4 \\
\hline Metastatik & 133 & 110 & $17,3 \%$ & 19,0 & 14,3 \\
\hline
\end{tabular}

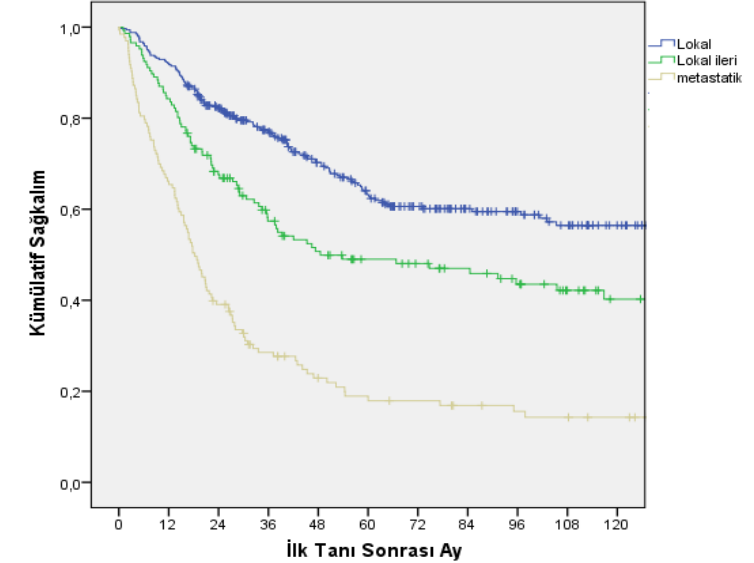

Şekil-16. Yumuşak doku sarkomları evrelere göre sağ kalım.
Hastanemizde kemik ve yumuşak doku sarkomlarında yıllara göre artış eğilimi görülmektedir ve bu artış istatistiksel olarak anlamlıdır (Şekil-17 ve 18).

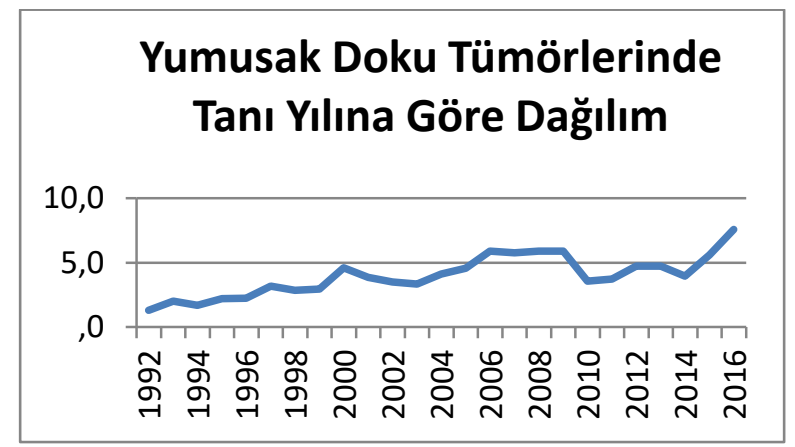

p<0,0001 doğrusal artış anlamlı

Şekil-17. Yumuşak doku sarkomlarının tanı yılına göre dağılımı.

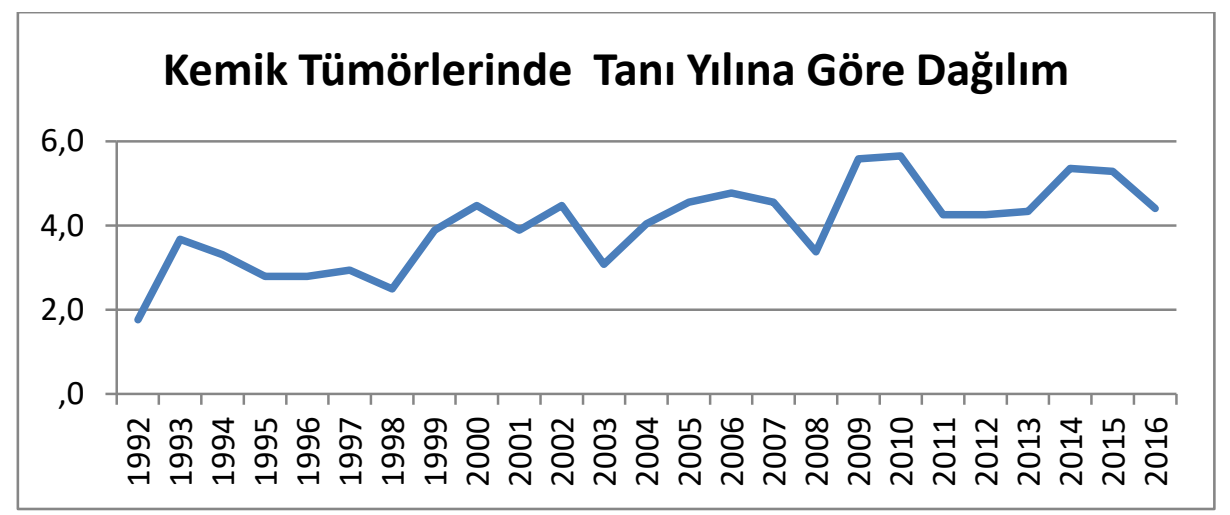

$(p<0,0001$ doğrusal artış anlamlı)

Şekil 18. Kemik tümörlerinin tanı yılına göre dağılımı. 


\section{Tartışma}

Kemik ve yumuşak doku sarkomları dünya genelinde nadir görülen tümörlerdendir. Ülkemize ait bu tümörlerle ilgili sağlıklı insidans verileri yoktur. Yaşa bağımlı değişim göstermekle birlikte Amerika ve Avrupa çalışmalarında yumuşak doku sarkomlarının yıllık insidans 1,8-6/100000 kemik sarkomlarının ise $0,6-2 / 100000$ olarak bildirilmektedir (11). Kaynaklarda tüm kanser olgularının yaklaşık \%1'ini kemik, \%1'ini ise yumuşak doku sarkomlarının oluşturduğu görülmektedir $(1,2)$. Bizim çalışmamızda da oranlar kaynaklarla benzerlik göstermektedir.

Kemik sarkomları özellikle genç erişkin yaş grubunda sık görülen yüksek dereceli tümörlerdir. Literatüre göre en sık görülen histolojik alt tip olan osteosarkom en sık ikinci dekatta görülür. İkinci pikini 50-60 yaş üzerinde yapar. Ewing sarkomunun ise \%50'den fazlası $10-20$ yaş aralığındadır. $\% 25$ ' $\mathrm{i}$ ise 10 yaş altında görülmektedir (3). Kondrosarkom en sık 30-60 yaş aralığında görülür ve yaklaşık kemik sarkomlarının \%20'sini oluşturur (12). Benzer şekilde bizim olgularımızda en sık osteosarkom ardından Ewing ve kondrosarkom saptandı. En sık 10-19 yaş grubunda olduğu görüldü. Ewing ve osteosarkom çocukluk döneminde belirgin görülürken, kondrosarkom ve kordoma ise ileri yaşlarda görüldü.

Yumuşak doku sarkomlarının görülme sıklığı yaşla birlikte artmaktadır. Olguların \%75‘i erişkin yaş grubundadır. Bizim de hasta grubumuzun büyük bölümünü erişkin yaş grubu oluşturmaktadır (13). Olgularımızın yaklaşık yarısı 50 yaş üstüdür. Literatürle benzer şekilde erişkin yaş grubunda en sık ekstremite yerleşimi görülmekte ve çocuk yaş grubunda ise ekstremite ile birlikte baş-boyun bölgesinde yerleşim sıklığı dikkati çekmektedir.

Sarkomlar özellikle genç erişkin dönemde görülen ve her yaş grubunu etkileyen mortalitesi yüksek tümörlerdir.

Trautmanna ve ark.'nın yapmış oldukları Almanya merkezli çalışmada YDS'de beş yıllık sağ kalım \%66,4 olarak saptanmış, kemik sarkomlarında ise \%52,9 saptanmıştır (8). Stiller ve ark.'nın Avrupa'da yaptıkları çalışmada ise beş yıllık sağ kalım oranları YDS'de \%57,8, kemik sarkomlarında ise $\% 61,6$ bildirilmektedir (9). Hastanemiz verilerinde saptadığımız sağ kalım oranları kaynaklarla uyum göstermektedir. Bizim çalışmamızda YDS da beş yıllık \%59 ve 10 yıllık \%49, kemik sarkomlarında $\% 62$ ve $\% 53$ saptandı.

Genel sağ kalım oranlarını etkileyen en önemli parametrelerden birisi tanı anında tümörün evresidir. Lokal evrede saptanan tümörlerde sağ kalım oranları iyi iken lokal ileri evre ve özellikle metastatik evrede sağ kalım oranları oldukça düşmektedir. Metastatik evrede GSK osteosarkomda \%30, Ewing sarkomunda \%22 oranlarına kadar düşmektedir $(6,14)$. Bizim olgularımızda kemik sarkomlarında beş ve 10 yıllık GSK değerlendirmemizde; Lokalize tümörlerde $\% 71$ ve $\% 65$ oranlarından, lokal ileri evrede $\% 58$ ve $\% 54$, metastatik dönemde ise \%43 ve \%36'lara kadar düştüğünü görmekteyiz.

Hem kemik hem de yumuşak doku sarkomlarında olguların yarısından fazlası lokal ileri evre ve metastatik evrede hastanemize başvurmakta. Bu durum nadir görülen bu tümörlerin geç tanı almaları ile ilişkilendirilmiştir. Kemik sarkomlarının genç yaş grubunda görülmesi nedeniyle çoğunlukla travma ya da büyüme ağrısı ile ilişkilendirilip tanıda gecikme olmaktadır. YDS'de ise kitlenin ağrısız ya da küçük olması gibi sebeplerden iyi huylu olduğu kanaati oluşmakta ve hastaneye geç başvurulara, tanıda gecikmelere yol açmaktadır.

Sonuç: EÜH Kanser veri sisteminde bulunan 117.139 olgu arasında kemik ve yumuşak doku sarkomları \%2,7 $\quad(n=3179) \quad$ oranında gözükmektedir. Yapılan sağ kalım değerlendirmesinde kemik tümörlerinde beş yıllık GSK \%62, 10 yıllık ise \%53 saptandı. Yumuşak doku sarkomlarında beş yıllık GSK \%59, 10 yıllık \%49 saptandı. YDS da GSK nın erkek hastalarda kadın hastalara göre daha kötü olduğu görüldü. Hem kemik hem de yumuşak doku sarkomlarında olguların yarısından fazlası lokal ileri evre ve metastatik evrede hastanemize başvurmakta. Lokal evrede saptanan tümörlerde sağ kalım oranları iyi iken lokal ileri evre ve özellikle metastatik evrede sağ kalım oranları oldukça düşmektedir. 


\section{Kaynaklar}

1. Weiss, S.; Goldblum, J. General considerations. In: Weiss, S.; Goldblum, J., editors. Enzinger and Weiss's Soft Tissue Tumors. St Louis, Missouri: CV Mosby, 2001: 1-19.

2. Unni KK, Inwards CY. Dahlin's Bone Tumors, 6th ed. Philadelphia: Wolters Kluwer, Lippincott Williams \& Wilkins, 2010.

3. Greenspan A, Jundt G, Remagen W. Differential diagnosis in orthopeadic oncology. 2 nd ed. Philadelphia: Lippincott Williams \& Wilkins, 2007.

4. Fuchs B, Ossendorf C, Leerapun T, Sim FH: Intercalary segmental reconstruction after bone tumor resection. EJSO 2008; 34 (12): 1271-6.

5. Mathew R, Di Caprio MD, Gary E, Friedlaender MD: Malign bone tumors; Limb sparing versus amputations. Journal of the American Academiy of Orthopaedic Surgeons 2003; 11: 25-37.

6. Picci P. Osteosarcoma (osteogenic sarcoma). Orphanet J Rare Dis 2007; 2: 6.

7. Böhm P, Fritz J, Thiede S, Budach W: Reimplantation of extracorporeal irradiated bone segments in musculoskeletal tumor surgery: clinical experience in eight patients and review of the literature. Langenbecks Arch Surg 2003; 387: 355-65.

8. Trautmanna F, Schulerb M, Schmitta J. Burden of soft-tissue and bone sarcoma in routine care Estimation of incidence, prevalence and survival for health services research. Cancer Epidemiology 2015; 39: 440-6.

9. Stiller CA, Trama A, Serraino D, Rossi S, Navarro C, Chirlaque MD, et al. Descriptive epidemiology of sarcomas in Europe: report from the RARECARE project. Eur J Cancer 2013; 49 (3): 684-95.

10.C.D.M. Fletcher. WHO Classification of Tumours of Soft Tissue and Bone. IARC. 4th Ed. 2013: 240-2.

11.Wibmer C, Leithner A, Zielonke N, Sperl M, Windhager R. Increasing incidence rates of soft tissue sarcomas? A population-based epidemiologic study and literature review. Annals of Oncology 2010; 21: 1106-11.

12. Murphey MD, Walker EA, Wilson AJ, Kransdorf MJ, Temple HT, Gannon FH. From the archives of the AFIP: imagining of primary chondrosarcoma: radiologic-pathologic correlation. Radiographics. 2003; 23 (5): $1245-78$.

13.Weis SW, Goldblum JR. Soft Tissue Tumors. 5th. Ed. Mosby, 2008.

14. Cotterill SJ, Ahrens S, Paulussen M, Jurgens HF, Voute PA, et al. Prognostic factors in Ewing's tumor of bone: Analysis of 975 patients from the European İntergroup Cooperative Ewing's sarcoma Study Group. J of Clinical Oncology 2000; 18 (3): 108-14. 